\title{
SNRPN Gene
}

National Cancer Institute

\section{Source}

National Cancer Institute. SNRPN Gene. NCI Thesaurus. Code C75575.

This gene plays a role in splicing of mRNA. 